\title{
Metalloproteinase inhibitors as a potential therapeutic approach in multiple myeloma: a preliminary study
}

\author{
A Sofia Pais ${ }^{1 *}$, A Cristina Gonçalves ${ }^{1,2}$, Catarina Geraldes ${ }^{1,3}$, José M Nascimento-Costa ${ }^{1,2,3}$, \\ Ana B Sarmento-Ribeiro ${ }^{1,2}$ \\ From 16th International Charles Heidelberger Symposium on Cancer Research \\ Coimbra, Portugal. 26-28 September 2010
}

Multiple Myeloma (MM) is one of the B-cell malignancies with a poor prognosis, characterized by the clonal expansion of neoplastic plasma cells within the bone marrow, elevated serum immunoglobulin, and osteolytic bone disease. The first pathogenic step is a premalignant monoclonal gamopathy of undetermined significance (MGUS). With progression of MGUS to myeloma, complex genetic/epigenetic events occur in the neoplastic plasma cell, and in the bone marrow microenvironment. The resultant interactions of myeloma cells, bone marrow stromal cells, and microvessels contribute to persistence of the tumour and resistance to drugs. Matrix metalloproteinases (MMPs) play a critical rule in bone remodeling (osteolitic lesions) and tumor invasion, and could be a new therapeutic target in MM.

The aim of this study is to evaluate the therapeutic potential of a metalloproteinase inhibitor, batimastat (BB-94), in a multiple myeloma cell line in culture.

For this purpose a MM cell line, the NCI-H929 [H929] cells were cultured in absence and presence of different concentrations of the MMP inhibitor, BB-94, during different periods of time. Cell viability and death was determined by the alamar blue assay and by flow cytometry using the annexin $\mathrm{V} /$ propidium iodide incorporation.

Our preliminary results show that BB-94 has, along a broad concentration range, an antiproliferative effect in MM cells that is accompanied by a cytotoxic effect as results of increased apoptosis levels as the concerntratio increases from 1 to $5 \mu \mathrm{M}$.

* Correspondence: anasofiaanasofia@gmail.com

${ }^{1}$ Faculty of Medicine, University of Coimbra, Coimbra, Portugal

Full list of author information is available at the end of the article
This study suggests that batimastat could be a new therapeutic approach in multiple myeloma in monotherapy.

\section{Author details}

${ }^{1}$ Faculty of Medicine, University of Coimbra, Coimbra, Portugal. ${ }^{2}$ Center of Investigation on Environment, Genetics and Oncobiology (CIMAGO), Faculty of Medicine, University of Coimbra, Coimbra, Portugal. ${ }^{3}$ University Hospital of Coimbra, Coimbra, Portugal.

Published: 24 September 2010

\section{doi:}

Cite this article as: Pais et al:: Metalloproteinase inhibitors as a potential therapeutic approach in multiple myeloma: a preliminary study. BMC Proceedings 2010 4(Suppl 2):P50.
Submit your next manuscript to BioMed Central and take full advantage of:

- Convenient online submission

- Thorough peer review

- No space constraints or color figure charges

- Immediate publication on acceptance

- Inclusion in PubMed, CAS, Scopus and Google Scholar

- Research which is freely available for redistribution

Submit your manuscript at www.biomedcentral.com/submit
Biomed Central 